\title{
Fictionality in Historical Television Series
}

\section{Péter Hajdu}

Shenzhen University, School of Foreign Languages, 3688 Nanhai Ave, Building H5, Office B106, Nanshan District, Shenzhen, Guangdong, 518060, China

https://orcid.org/0000-0002-3623-1578

pethajdu@gmail.com

The most obvious formal feature of the historical novel as the genre founded by Walter Scott is the duplicity of a fictional foreground story and a historically approved background. Many television series have a historical past setting, and many of them can be seen as similar to historical novels. The 2005-07 series Rome kept something of the Scottian structure of fictional foreground story. The Pullo and Vorenus story line is fictional, and it stages the life of ordinary people, while historical characters like Julius Caesar and Pompey or Antony and Augustus do not merely form a factual background. The fictional and non-fictional stories are in balance, and they together offer a vivid and convincing representation of the past. Many historical television shows use the past only as decorative setting for a story full of intrigue, violence and sex (The Tudors, The Borgias). These may be described as historical (anti)romances, which tend to focus exclusively on the elite. Another kind of historical novel has been developed by some shows that (as if at the other extreme) eliminate the historical facts even from the background and represent everyday life of ordinary people in its (semi-) historical otherness. In shows like Mad Men or The Knick, no event of political history is mentioned, no historical person appears in the background. However, these shows successfully represent the otherness of the past from the viewpoint of public discourse on issues of race, gender, or even morality, phenomena which can be regarded as the development of a new kind of historical novel encouraged by the twentieth-century ideals of historiography.

Keywords: historical novel / television series / fictionality / realism / documentarity / anachronism / Rome / Mad Men

It is hardly a surprise that in the context of postmodernism's sensitivity to historical knowledge, and the rise of quality television, several TV series have approached historical material. This art form solicits comparison to the long literary narrative on history, i.e. the historical novel. Some television series show remarkable similarities to the Scottian archetype, which focuses on fictional everyday characters while trying to 
draw a reliable picture of political history in the background; others experiment with new kinds of historical narrative, either through retelling stories of the political elite attested by historiography, or eliminating political history to focus on everyday life in the past. The latter approach seems to result in more interesting works, maybe due to its affinity to the twentieth-century criticism of historiography that emphasized the importance of understanding the life of the underprivileged and hearing the voice of the oppressed.

According to György Lukács's definition, not every novel with past setting is a historical novel, only those that belong to the realist tradition initiated by Walter Scott, who is generally regarded as the founder of the genre, and have "the specifically historical, that is, derivation of the individuality of characters from the historical peculiarity of their age" (Lukács 19), novels that represent the past in connection to the present and by doing so discuss crucial problems in the lives of the people. Many romans historiques (which means historical novels) were produced in eighteenth-century France, and they even made use of the formal feature which appears as obligatory and genre-constituting in the later development, namely the duplicity of a fictional foreground story and a historically attestable background. ${ }^{1}$ Scott, who knew this kind of French literature, did not invent but always applied that feature, as did most nineteenth-century historical novels following in his wake. The prestige of historical novels had its ups and downs through history; there were times when the genre was highly appreciated and times when it was regarded as entertaining literature mostly for youth. High-brow literature tended to take an ironic stance towards the traditional form of historical novel in the second half of the twentieth century, which can be clearly seen in what Linda Hutcheon called historiographical metafiction (Hutcheon 105-231), but also in Stefan Heym's The King-David-Report (1973), which can be put in that category only with some difficulties. ${ }^{2}$ The genre has, however, kept much of its vitality, at least as popular fiction.

${ }^{1}$ Lukács was well aware of "novels with historical themes," some "'precursors' of the historical novel" also in China or India, and "the so-called historical novels of the seventeenth century," but he did not think they have anything to do with "the phenomenon of the historical novel" (Lukács 19). In a posthumously published paper Mihály Szegedy-Maszák tried to work with a more inclusive generic definition, which embraces eighteenth-century French novels and postmodernist works as well (Szegedy-Maszák passim).

${ }^{2}$ Hutcheon does not mention Heym, which allows one to come to the conclusion that an ironic stance towards history and historical knowledge may appear also outside the realm of historiographic metafiction. 
With the rise of the quality television series as a prestigious form of cultural production, which can achieve not only immense popularity but also critical acclaim and academic interest, and may have become the most important artistic form of our times, historical series have appeared too. Some television series with a historical setting can be seen as similar to historical novels, and their cumulative length can even challenge some monumental printed examples from the nineteenth century, like Tolstoy's War and Peace. In my calculation it takes approximately 52 hours to read War and Peace; to have such time of entertainment one needs 5 or 6 seasons of a series. In the history of television, the serial format was first applied long ago, but the lowbudget simplistic form of two decades ago is obviously not the same we are watching today. ${ }^{3}$ There seems to be an essential link between the serialized realist novel of the nineteenth century and the present television series, which mostly adapts a realist aesthetics (Goodlad passim). In accord with the general opinion I take as starting point of the rise of television series the production date of the Sopranos, i.e. $1999 .{ }^{4}$

The first major attempt at a historical television series was Rome by $\mathrm{HBO} / \mathrm{BBC}$ (2005-07) that kept something of the Scottian structure of fictional foreground story and historical background facts. The Pullo and Vorenus story line may be regarded as the fictional foreground, which stages the life of ordinary people, but historical characters like Julius Caesar and Pompey or Antony and Augustus do not merely form a factual background. The names of Titus Pullo and Lucius Vorenus are historically verified, since they appear in Julius Caesar's commentary on the war in Gaul. Caesar wrote one chapter about one of their deeds (Book 5, Chapter 44), when in spontaneous competition of heroism they helped and saved each other in fight against a Gallic tribe. According to that report they were both centurions, enemies of fierce rivalry, and both great fighters. Only the last feature has made its way

${ }^{3}$ I think the difference in quality, complexity and sophistication is obvious, but I have to admit that not for everybody. In his article on "Televising Antiquity," Jon Solomon narrated a continuous history of miniseries on antiquity which naturally and without any bigger jump went on with (post-Sopranos) Rome. His conclusion was that "the huge budget, the multi-layered narrative, the enormous cast of characters, the sexual titillations and contrasting extremes of morality, the densely packed and constantly varied screen visuals, and the segmented broadcasts as well as the pre-broadcasting and postbroadcasting promos, trailers, and teases all have their precedents in the earlier examples of the genre" (Solomon 26). However, the aesthetic gap between the miniseries he refers to and Rome could not be wider.

${ }^{4}$ Lauren Goodlad, for example, spoke of " $\left.\mathrm{t}\right]$ he game-changing aesthetic prestige of The Sopranos" (Goodlad 321). 
into their representation in Rome. When we first meet them in the series, Vorenus is a centurion, but Pullo is just an undisciplined regular soldier under his command. They are neither enemies nor rivals, and despite their initial dislike they gradually become best friends. The only episode of their lives told by Julius Caesar has not been used by the creators of the show, but they are involved in many fictional and semifictional events from Gaul to Rome, to Greece and Egypt. Their life stories are therefore fictional, with the only historically attested features of the names and their exceptional fighting skills. And these two characters provide the opportunity to represent the life of the lower social strata of Roman society with their morals, lifestyle, aims, and also the objects they use in everyday activities. Rome, however, does not only represent the life of people like Pullo and Vorenus, but retells in detail the political history of what is usually called today the Roman revolution. The fictional and non-fictional stories are in balance, and together offer a vivid and convincing panorama of the past. And the show invents many ingenious moments to connect the two social strata of the story; such points of juncture are omnipresent, as when Julius Caesar uses Lucius Vorenus as his personal bodyguard, when Atia employs Titus Pullo as her son's personal trainer, when the two of them are sent out by Caesar to save Cleopatra and bring her to Alexandria, or when Marc Antony commissions Pullo to execute Cicero. ${ }^{5}$

They are always present where something important is about to happen in Roman history, ${ }^{6}$ but they have quite different viewpoints and interests from those of the Roman nobility, which does not mean Vorenus and Pullo's worldviews are identical. Vorenus represents a naïve belief in traditional Roman values, shared by hardly anybody from the rather cynical ruling classes, while Pullo gives into the show an appetite for life and joy unadulterated by moral or ideological restrains. The contrast of the two social layers also has humorous potentials, both in a harsh and a more refined register. An example of the latter can be

${ }^{5}$ Cicero's death scene is discussed by Eran Almagor as a perfect opportunity for the interplay of fact and fiction, since the historical facts were "obscured by clouds of fiction" "from the outset" (Almagor 61). Since "despite having a range of source material on this event which is, relatively speaking, extremely wide, we know very little indeed about what actually happened" (Wright 452), it is even possible to insert Pullo in the gap of knowledge (although some sources attest that the killer's name was Popillius) and imagine a dialogue in the manner ancient suasoriae did. The fine analysis regards Rome's strategies in creating historical narrative as rather similar to ancient historiography.

${ }^{6}$ That is why Monica S. Cyrino calls them "the heart and soul of Rome's narrative trajectory," and likens Pullo to Forrest Gump (Cyrino, "Introduction" 4, 6). 
the scene in which Cicero foretells that killing him provides immortality to Pullo ("Philippi," S02E06).

Cicero: I dare say your work today will earn you immortality.

Pullo: How's that?

Cicero: I will be in all the history books. My killer's name, no doubt, will live on also.

Pullo: Oh, my name ... Thought you meant me.

The misunderstanding follows from their different value systems: fame, a central value of any aristocracy, does not mean anything to Pullo. He would be enthusiastic to gain immortality in person, and he is naïve and uneducated enough to imagine it is possible, but could not care less about the presence of his name in history books. The value conflict is more complex than the traditional Hollywood clichés of "a debauched upper class who provide titillation and shock value, and a sympathetic, hard-working lower echelon who embody 'values' we recognize" (Haynes 51). ${ }^{7}$

It would be, however, an oversimplification to associate fictionality with low-social-strata characters and factuality with the Roman elite. The life and character of Atia, Caesar's niece and Octavian's mother, is hardly more attested by historical evidence than those of Vorenus. And the little we can learn from historical sources overtly contradicts her circumstances in the TV show. During the times represented in Rome she was not a single mother but married to a certain Lucius Marcius Philippus. ${ }^{8}$ The shrewd widow, the promiscuous, highly independent Atia, the authoritative mother as the head of her family in the absence of any adult male figure, is rather fictional, but obviously has great potential both for Octavian's bildungsroman (see Weiden Boyd) and the development of an alternative, gendered system of power relations in the series' narrative (see Cyrino "Introduction"; Toscano). Historical evidence tends to inform us of the life of privileged men, and if we also consider stories about privileged women as part of the fictional foreground story of Rome, the relationship to the factual narrative becomes balanced and more similar to the Scottian proportions.

The show is also exemplary from the viewpoint of necessary anachronism-to use an expression coined by Lukács in a broader sense. For

${ }^{7}$ Also cf. Haynes's note 2 on page 59 on the Hollywood clichés origins with further bibliography. For a different contrast of upper and lower class moralities see (Toscano 164).

${ }^{8}$ Suetonius, Augustus 8; see also Dio 45.3-4. 
Lukács it was mostly a linguistic feature of the historical novel: historical characters should not speak an idiom that is historically accurate. ${ }^{9}$ Their speech must be anachronistic so that readers understand them. It goes without saying that in the show everybody, be Roman, Greek or any kind of barbarian including Jews, speaks English. ${ }^{10}$ But the show uses some visual means too to make the represented past alien and familiar at the same time. It avoids radical historical accuracy without total domestication of the visual environment. The half painted public buildings, especially temples, are a case in point. Viewers probably associate the image of ancient temples with bright whiteness. To show white buildings in the television would have been completely anachronistic, since-as archaeologic evidence proves - the ancient buildings were painted. However, the creators chose not to shock their public with painted surfaces of the familiar shapes of classic buildings. What one sees in the show is half-painted temples; painted for historical accuracy, white for the necessary anachronism, to link the experience to modern predispositions. One may say that the show makes the audience meet the past half way in many aspects of the visual environment. This strategy must be part of what Cyrino calls the "process of creating an authentic, but not always accurate, onscreen portrayal of antiquity" (Cyrino "Atia" 7). ${ }^{11}$

Letters and messages may serve as another, although less spectacular example. The most usual material to write messages on in ancient Rome was waxen tablets, as we know both from textual and visual representations. In Rome tablets appear sporadically, but people mostly use rolls of something similar to our paper. In the pilot four letters appear. First a soldier delivers Pompey's letter to Julius Caesar. After the delivery scene we see Caesar's face reading the letter while we hear Pompey's voice telling about Julia's death. Then the film actually

${ }^{9}$ More accurately, when Lukács introduces the notion (referring to Goethe and Hegel), speaks mostly about the characters' consciousness: “[T]he writer would allow those tendencies which were alive and active in the past and which in historical reality have led up to the present (but whose later significance contemporaries naturally could not see) to emerge with that emphasis which they possess in ... the present" (Lukács 61-62). In his most detailed analysis of the problem, however, he focuses on linguistic issues (195-198).

${ }^{10}$ Apart from several minor cases of code-shifting, the most interesting of which are those in ritual context (Briggs 201-204).

${ }^{11}$ Or what Kristina Milnor summarized in much less favorable terms: "The producers of Rome wanted Romans who were different, but not too different," because "for them, authenticity was in the impressive details, the titillating finishing touches" (Milnor 45, 48). 
shows the death scene without narration. The latter technique does not feature in the episode's other letter reading scenes. Brutus delivers Caesar's letter to Servilia, we see Servilia read it and hear Caesar speaking to her. The third letter is Caesar's to Atia, which appears without the delivery. Atia reads while listening to Caesar's voice. In these three cases the letters are written on a material that looks like fine paper with uneven edges. The first two messages are also shown before reading as rolls. Paper would be anachronistic, therefore we may take that material for papyrus, but listeners do not need to know. The fourth letter is sent by Caesar to Pompey, and it is written on wax tablets. With three scenes the show has satisfactorily established the narrative pattern of reading letters. A person looks at the message while we listen to the voice-over reading by the sender. The feature that the letters are rolled and not folded gives them enough historical air. For the fourth letter the show dares venture historically more accurate material. The very unfamiliar object of the double tablets as carrier for written messages is easily understandable from the already familiar narrative frame. Pompey is looking at that object while we listen to Caesar's voice speaking to him. It must be a letter.

The lack of intellectual topics is an aspect in which the limits of a historical television series becomes visible. The politics represented in the show (maybe made anachronistically similar to modern politics) lacks intellectual content, and therefore hardly anything is mentioned about the erudition of the characters. It is not by chance that figures like Virgil ${ }^{12}$ or Horace do not appear in the show. Maecenas is a secondary character in season 2, an effeminate guy mostly moved by greed, of whom nobody would imagine that he attracts and enjoys the company of the finest minds and the greatest poets of his time, some of them maybe the greatest of all times. Julius Caesar is clever, wise, impressive, but hardly anybody who would care to create fine prose or write treatises about linguistics. Cicero is represented as a sorry loser; you would not believe of that person that he was one of the greatest orators of history who in his free time created the basic lexicon of European philosophy. The teenage would-be-Augustus writes tragedies in season

${ }^{12}$ Actually Virgil's poetry (not the poet as a character) appears in a rather strange way. In episode "Stealing from Saturn" S01E04 Atia forces her daughter Octavia to entertain her party guests with some poetry, because "she can rattle off pages of the stuff." Octavia quotes Aeneid 6.126-129, and as Ward Briggs wittily remarks, she "exits the party before we realize that she has lost not only her husband but also her place in time" (Briggs 203), since the dramatic moment precedes the writing of those lines by more than twenty years. 
1, and he also quotes Catullus' Poem 2 to his sister (S01E09), but this seems a childish pastime in retrospect, since any interest in literature disappears from him at the moment he starts acting as a politician. The Roman elite's enthusiastic interest in philosophy, history, poetry does not feature in the show, probably because it would not contribute to the action, while making characters too complex.

With all its popular features, with all its concentration on the personal, Rome explains a major historical change in Roman society, and the Scottian duplicity of average fictional personnel and well documented characters of the elite helps to represent the crucial problems of the society. This statement might be strong; the critical response to the balance of what historians call history and the focus on private as the carrier of novelistic narrative is polarized. Some critiques find the focus on the private sphere ahistorical and "cheap," to use Brutus's evaluation of what he wants to avoid in Caesar's assassination. He rejects the idea of poisoning the tyrant, because "this is not some cheap murder," and wants a public, theatrical performance, while the story line suggests that Caesar has to die because of the revenge of his abandoned lover Servilia, who uses her son Brutus and the other conspirators as her puppets; this way the show displays the assassination as a basically private action, which is emphasized by Vorenus's parallel drama of jealousy, which ends with the death of his wife Niobe (Futrell 109-113). ${ }^{13}$ Others will find that "the genius of the series Rome lies in its depiction of power as intricately complex, many-layered, always shifting, unstable, and never focused on just the privileged few" (Toscano 154).

This, however, is not the usual strategy. Many historical television shows use the past only as decorative setting for a story full of intrigue, violence and sex. Those may be described as historical (anti)romances. They tend to focus exclusively on the elite, without an ordinary-people story-line, which obviously could not be so decorative. These can be examples of an approach to the past that rather avoids the ordinary. Stories about rich people who wear beautiful clothes, live in grand palaces and magnificent gardens, but seldom care about anything but personal interest, money and desire, and maybe family. The Tudors and The Borgias by Showtime (2007-10 and 2011-13, respectively) are suitable examples; ${ }^{14}$ they can be called anti-romances, because their general attitude is the negation of the values cherished in romances.

${ }^{13}$ See also the devastating critic of Season 2 (Bianco 2007).

${ }^{14}$ Lauren Goodlad called the former "a mix of biopic and blue movie," which accurately describes both its focus and its lack of historical interest (Goodlad 321). 
When there is a basic conflict between two forces, they are not good and evil (as in a traditional romance), but between two equally evil groups among the elite. Ordinary people with their ordinary problems cannot appear in such a context.

I am inclined to regard such shows as one of the possible extremes of historical television narrative, the one focusing exclusively on the elite, which also means, on historical characters whose existence is verifiable by evidence. The other extreme can be found in some shows that eliminate the grand historical facts even from the background and represent the everyday life of ordinary people in its (semi-)historical otherness. In shows like Mad Men (Lionsgate 2007-15) or The Knick (Cinemax 2014-16) no event of political history is mentioned, no historical person appears in the background. However, these shows successfully represent the crucial problems of the life of the people in their everyday reality, and also the otherness of the past from the viewpoint of public discourse on issues of race, gender, or even morality. The ordinary is represented as strange here.

The lack of historical background events is not totally complete in Mad Men, but it is a basic difference from the traditional (written) historical novels that the background is much more literally a background. In historical novels the figures familiar from history books tend really to appear; in the background, but as background characters. Important historical events still tend to be narrated, even if they are not decisive for the fictional characters' personal life story. In this show, however, what is usually regarded as history is merely mentioned by the characters, for example in elevator chats. In the first season the 1960 presidential elections are mentioned several times, but mostly from the viewpoint of advertisement professionals who wonder which candidate appears better in television ads. Politics is just another product and in the represented community nobody cares about the political content of the candidates' messages, nobody seems to wonder what is at stake, they only evaluate the achievement of the campaign teams in selling their product. Kennedy's face appears in leaflets or TV ads that characters are looking at. After the election night Bert Cooper explicitly explains to Don Draper that Kennedy's presidency will not influence their business. Political history or the history of the highest elite does not seem to bother anyone. In the same episode that discusses the elections in most detail, S01E12 entitled "Nixon vs. Kennedy," one can also see a flashback from the Korean War, which explains Don's past, how he had gained a new identity to break all the ties to the family and the past he hated. The Korean War appears as a haunting memory, a past that 
should be stayed buried, the return of which Don fears the most. The war, as it is represented in the show, is not a major historical event of the American nation or in the conflict of global superpowers, but a personal affair of the protagonist that should stay forgotten. And he seems to share this attitude with the majority. Only Roger Sterling speaks about some war memories once when he is so drunken that he even tries to hit on Don's wife. The same can be said about the Vietnam war in Season 5, news of which rarely appear, "most often through brief news reports on TVs in the background of scenes" (Polan 44).

The assassinations of Robert Kennedy and Martin Luther King have a major impact on the emotions of all the characters, and whole episodes are built around them (S03E12 and S06E05 respectively). The death of these figures of historical importance is not directly shown: we see how the characters see those events on TV, how they learn about them. In this way they are in the background, but the events massively influence what happens to the characters in the given episodes. However, an earlier episode (S02E09) provides a caveat: Marilyn Monroe's death by overdose has exactly the same kind of impact on the represented microcosm. The three episodes together suggest that what is at stake is not a factual historical event that is so important that it breaks through from the narrative background, but the death of a celebrity, a shocking piece of the news flow can temporarily unsettle the story-world.

Nevertheless, many viewers have gone so far as to call Mad Men a documentary. This impression may partially stem from the accurate representation of clothes, furniture, inner design, and various objects. The creators of the show invested immense energy in the realistic appearance of the visual environment, ${ }^{15}$ which, however, does not exclude minor anachronisms for artistic purposes or other reasons. Already in the pilot Joan Holloway praises the IBM Selectric typewriter used in the office in the dramatic time of March 1960, while these were not introduced earlier than June 1961. "Matthew Weiner has said that he knew that this was an anachronism, but the more period-correct 1960 models were harder to come by and repair, and also much louder,

15 'In the exhibition 'Matthew Weiner's Mad Men' at the Museum of the Moving Image in New York, visitors could see the attention to detail Mad Men lavished on items that were only briefly on camera. Some, in fact, were never seen at all, and were only created to help the actors get into the right headspace. Don, Roger, Pete, and Joan all have business cards. Don's wallet includes a driver's license and a picture of young Sally and Bobby in a toy wagon. Even the secretaries' desk drawers contain period knickknacks and sixties-appropriate personal mementos" (Zoller Seitz footnote 13 to S05E13, a note written by Amy Cook). 
which created more sound issues" (Zoller Seitz footnote 8 ad S01E01). The difficulty of finding the correct model is technical, and the sound it would make is a rather artistic problem that could have been avoided by a minor anachronism, while the model that appears on screen is still characteristic of the period. Such minor anachronisms might happen by mistake (although nowadays studios can count on fans to spot the anachronisms), but more probably by conscious decision, as in the case of S04E03 when Draper and Lane watch the Japanese movie Gamera on December 31, 1964, despite its not having been released till November 1965. The film was too good for artistic purposes, while being characteristic of the period, to dismiss because of some minor chronological scruples.

But the show seems also reliable as a representation of past mentalities and discourses. Nineteenth-century historiography was much criticized for exclusively focusing on elite political history and neglecting the life of the people. The latter was an area in which the historical novel was competing with historiography. As is well known, twentiethcentury historians developed several methods to widen the scope of their discipline, the most successful of which is microhistory. Mad Men can be regarded as an attempt at a kind of historical fiction that gets rid of the ballast of elite political history to represent the everyday life of the past in its otherness.

Another question that could be raised is if the 1960s are remote enough to be called history. According to Jan Assmann the floating gap between communicative memory and cultural memory (to the latter of which historiography might contribute) is about 80 years back in time (e.g. Assmann 2013). Walter Scott in the novel which is generally regarded as the founding piece of the tradition, namely Waverley, represented events that had happened 70 years earlier. The 50 years of the Mad Men is still something reachable for the communicative memory through the personal experience of many people still alive around us. Three answers might be given to this question. The first would be that we have experienced the changes in everyday mentalities and discourses as so rapid in the last decades that 50 years ago might appear as historical times. The second would be that American TV studios work not only for the US but also for a global market, while even the US audience is much too broad to be able to have a unified communicative memory. New York of the 1960s is not something that most spectators can reach through communicative memory, the lack of which might make it history. This answer implies that the measure of the time-gap is only enough to establish historicity inside a given culture, and oth- 
erwise a more complex spatio-temporal scrutiny is needed. Non-local readers of postcolonial writing may learn something like history even if the time-gap between the reading and the represented social reality is much narrower than the floating gap required by Assmann. For the availability or lack of witnesses let me quote a passage from Matt Zoller Seltz's complete recap collection:

Even in its freshman season, Mad Men was criticized in some quarters as a caricaturish wallow in a Generation X-aged writer-producer's fantasy about the go-go lives of his parents' generation: a series that amped up the era's smoking, drinking, infidelities, and male chauvinism to absurd levels while reveling in the antics it supposedly critiqued. Funny thing, though: A lot of people who worked on Madison Avenue in the sixties have insisted that Mad Men doesn't exaggerate that much. (Zoller Seitz 65)

Could or could not the audience reach that particular past through communicative memory? From the first part of the quotation one can conclude that they could not. But a lot of eyewitnesses, even if they must be very old, are still around. With the aid of current technologies of communication, they reacted to the false claims of those who had no access to that memory. Assmann spoke about the communicative memory of a community, and probably did not consider the possibility of virtual on-line communities and communication. The answer therefore depends on the acceptance of the intervention of a lot of people who worked there as communicative memory on a global scale.

The third answer would be simply negative, namely that Mad Men should not be called historical, because the represented past is not remote enough. One does not have to face such a problem with The Knick, which is set in the beginning of the twentieth century. It is a hospital story, and does not only shock with the sexism, racism, and antisemitism of the everyday discourse, but also with the maybe naïve approach to drug addiction (and addictive drugs), and the brutal treatment of the patients, especially the mentally ill. The Knick contains even fewer references to political or large-scale historical events than Mad Men. The show focuses exclusively on the life of doctors, nurses, ambulance drivers, patients - and hospital owners, bookkeepers, construction entrepreneurs, and the criminals connected to them. Still, the show can make one realize major historical changes in the way we live, which changes of course are mostly results of painful struggles, and have not, alas, arrived at a final point in which we can happily live ever after.

Nevertheless, it can be argued that shows like Mad Men and The Knick suggest exactly that. They can be examples "of those cases in 
which criticism of the past is used to congratulate the present," because "everything right today was wrong back then" (Greif). It might very well be the case, but practically these shows do not tell anything about the present explicitly, but rather highlight features of the past that were radically different and therefore solicit comparison. Or to put it another way: "the show isn't about history"; "[t] he people of Mad Men do things and have things done to them while history rolls forward.... It's about human behavior occurring in the moment. It doesn't explain. It observes. It's not about the period; it's about the question mark" (Zoller Seitz 426-427). But it depends on the recipient's decision or attitude to which kind of conclusion to come. That can easily be "now we know better" but also "we still have a lot to do," not to mention the possibility of a nostalgia for those times when people were allowed to be racist machos without being frowned upon.

And while following the lives of several people throughout the 1960s the show seems to represent some changes that can be called historical; changes of attitudes and moralities. In Season 1 sexual harassment of women appears as a daily office routine, and Peggy Olson struggles to be the first female copywriter. In Season 6 women seem to have a rather different position in the company, to face the old fashioned degradation and humiliation when their firm joins a big corporation in Season 7. Even if a historical change is visible, it is far from being an unilinear movement which has homogeneous speed in every location, social stratum, or corporate level. Non-white characters are hardly present in Season 1, a janitor, Hollis, the elevator operator, the Drapers' housekeeper. Later the company will employ two African-American secretaries. Pete Campbell makes a remark in S01E8 that can be understood as racist, expressing his dissatisfaction about having to share the elevator space with the African-American janitor because the service elevator is out of order; it is not evident if his problem is the intruder's social status or race or a mixture of the two. In Season 3 he is the one who discovers the potentials of a "negro market," and in his enthusiasm he tries to engage in a conversation with Hollis - an attempt not accepted favorably, but at least it ends with them laughing together. ${ }^{16}$ In Season 6 it will be Campbell who accuses Harry Crane of racism. In his progress we can see a hint at a historical change, even if it is a very cautious hint. ${ }^{17}$

${ }^{16}$ S03E05. It is true, however, that the laughter can be interpreted in very different ways (see Lang; Joyrich 221-24; Ono).

${ }^{17}$ Matt Zoller Seitz criticizes the show of avoiding the racial issues and handling them too cautiously or superficially (Zoller Seitz passim). 
Environmental issues are hardly ever in the focus in Mad Men, but S02E07 can exemplify the problematic nature of the wrong past/correct present dichotomy. First ad men discuss the pros and cons of Pampers' new product, the disposable diapers, which ends in the middle. Even if Sal Romano thinks that "ten cents apiece, you kind of think you should reuse them," Ken Cosgrove's conclusion may stick in the mind: "and the greatest benefit of all, you can throw them away." Really? Throwing things away as a greatest benefit? Later in the same episode, the Drapers have a picnic in the green. When the idyllic scene ends, Don throws away his empty beer can with full concentration and great effort, and Betty simply throws off the garbage from their blanket. For an uncut 40 seconds, while they drive away, the garbage on the grass stays almost in the center of a well composed landscape picture. This episode entitled "The Gold Violin" is not about garbage issues ${ }^{18}$ (notwithstanding the fact that it happens in this episode that Jimmy Barrett calls Don Draper "garbage"), but they are much more present than in any other episode. But does this minor subtext really suggest that back then the attitude to littering was wrong and is good now? Is the problem of land garbage satisfactorily solved? Are the days of naïve, easy-going polluting gone? Even if upper middle class families might not leave their garbage on the grass after a picnic nowadays (or might they?), the issue of garbage is still very much central to our present concerns. And I would not exclude the possibility that one can feel nostalgia for the days when irresponsible garbage production did not elicit any feeling of guilt.

From the viewpoint of the fictional plot of everyday characters I have discussed three positions in the possible spectrum from none to exclusivity. I found the former the less interesting from the aspects both of art and history. The more or less balanced middle represented by Rome is an outstanding achievement, which is the most similar to the historical novel. The exclusively everyday plot may result in a new kind of historical novel which is closer to the twentieth-century ideals of history or historiography.

${ }^{18}$ Matt Zoller Seitz finds this episode quite unfocused simply "revisiting ides the series has spotlighted before," which results in "the first installment of Mad Men that feels largely superfluous" (Zoller Seitz 111). 


\section{WORKS CITED}

Almagor, Eran. "Earning Immortality: Cicero's Death Scene in Rome." Rome, Season Two: Trial and Triumph. Ed. Monica S. Cyrino. Edinburgh: Edinburgh University Press, 2015. 61-73.

Assmann, Jan. "Communicative and Cultural Memory." The Theoretical Foundations of Hungarian "lieux de Mémoire" Studies. Ed. Pál S. Varga, Karl Katschthaler, Donald E. Morse, and Miklós Takács. Debrecen: Csokonai Kiadó, 2013. 36-43.

Bianco, Robert. "Rome Goes into Decline." Usatoday.com 11 Jan. 2007. Web 12 Jan. 2020.

Briggs, Ward. "Latin in the Movies and Rome." Rome, Season One: History Makes Television. Ed. Monica S. Cyrino. Malden: Blackwell, 2008. 193-206.

Cyrino, Monica S. "Introduction." Rome, Season One: History Makes Television. Ed. Monica S. Cyrino. Malden: Blackwell, 2008. 1-10.

Cyrino, Monica S. "Atia and the Erotics of Authority." Rome, Season One: History Makes Television. Ed. Monica S. Cyrino. Malden: Blackwell, 2008. 130-140.

Futrell, Alison. "'Not Some Cheap Murder': Caesar's Assassination.” Rome, Season One: History Makes Television. Ed. Monica S. Cyrino. Malden: Blackwell, 2008. 100-116.

Goodlad, Lauren M. E. "The Mad Men in the Attic: Seriality and Identity in the Modern Babylon." Mad Men, Mad World: Sex, Politics, Style and the 1960s. Eds. Lauren M. E. Goodlad, Lilya Kaganovsky, and Robert A. Rushing. Durham: Duke University Press, 2013. 320-344.

Greif, Mark. "You'll Love the Way It Makes You Feel." London Review of Books 23 Oct. 2008. Web. 12 Jan. 2020.

Haynes, Holly. "Rome's Opening Titles: Triumph, Spectacle, and Desire." Rome, Season One: History Makes Television. Ed. Monica S. Cyrino. Malden: Blackwell, 2008. 49-60.

Hutcheon, Linda. The Poetics of Postmodernism. London: Routledge, 1988.

Joyrich, Lynne. "Media Madness: Multiple Identity (Dis)Orders in Mad Men." Mad Men, Mad World: Sex, Politics, Style and the 1960s. Eds. Lauren M. E. Goodlad, Lilya Kaganovsky, and Robert A. Rushing. Durham: Duke University Press, 2013. 213-259.

Lang, Clarence. "Representing the Mad Margins of the Early 1960s: Northern Civil Rights and the Blues Idiom." Mad Men, Mad World: Sex, Politics, Style and the 1960s. Eds. Lauren M. E. Goodlad, Lilya Kaganovsky, and Robert A. Rushing. Durham: Duke University Press, 2013. 73-91.

Lukács, Georg. The Historical Novel. Trans. Hannah and Stanley Mitchell. London: Merlin, 1989.

Milnor, Kristina. "What I Learned as an Historical Consultant for Rome." Rome, Season One: History Makes Television. Ed. Monica S. Cyrino. Malden: Blackwell, 2008. 42-48.

Ono, Kent. "Mad Men's Postracial Figuration of a Racial Past." Mad Men, Mad World: Sex, Politics, Style and the 1960s. Eds. Lauren M. E. Goodlad, Lilya Kaganovsky, and Robert A. Rushing. Durham: Duke University Press, 2013. 300-319.

Polan, Lana. "Maddening Times. Mad Men in Its History." Mad Men, Mad World: Sex, Politics, Style and the 1960s. Eds. Lauren M. E. Goodlad, Lilya Kaganovsky, and Robert A. Rushing. Durham: Duke University Press, 2013. 42-60.

Solomon, Jon. "Televising Antiquity: From You Are There to Rome." Rome, Season One: History Makes Television. Ed. Monica S. Cyrino. Malden: Blackwell, 2008. $11-28$. 
Szegedy-Maszák, Mihály. "A történelmi regény létezési módja.” Müfaj és komparatisztika. Eds. Dorottya Szávai and Zoltán Z. Varga, Budapest: Gondolat, 2016. 57-67.

Toscano, Margaret M. "Gowns and Gossip: Gender and Class Struggle in Rome." Rome, Season One: History Makes Television. Ed. Monica S. Cyrino. Malden: Blackwell, 2008. 153-67.

Weiden Boyd, Barbara. "Becoming Augustus: The Education of Octavian." Rome, Season One: History Makes Television. Ed. Monica S. Cyrino. Malden: Blackwell, 2008. 87-99.

Wright, Andrew. "The Death of Cicero: Forming a Tradition: The Contamination of History." Historia 50 (2001): 436-52.

Zoller Seitz, Matt. Mad Men Carousel: The Complete Critical Companion. New York: Abrams, 2015.

\section{Fikcijskost $\mathrm{v}$ zgodovinskih televizijskih nadaljevankah}

Ključne besede: zgodovinski roman / televizijske nadaljevanke / fikcijskost / realizem / dokumentarnost / anahronizem / Rim / Oglaševalci

Najočitnejša formalna lastnost zgodovinskega romana kot žanra, ki ga je vzpostavil Walter Scott, je dvojnost fiktivne zgodbe v ospredju in zgodovinsko potrjenega ozadja. Dogajališča mnogih televizijskih nadaljevank so zgodovinska, mnoge od nadaljevank je mogoče videti kot zgodovinske romane. Televizijska serija Rim (2005-2007) je ohranila nekaj scottovske strukture, značilne za izpostavljeno fikcijsko zgodbo. Zgodba o Pulosu in Vorenusu je fikcijska in uprizarja življenje preprostih ljudi, zgodovinski liki, kot so Julij Cezar in Pompej ali Antonij in Avgust, pa ne nastopajo zgolj kot na zgodovinskih dejstvih temelječe ozadje. Razmerje med fikcijskimi in nefikcijskimi zgodbami je uravnoteženo, in kot tako ponuja živ in prepričljiv vpogled v preteklost. Mnogim zgodovinskim nadaljevankam preteklost služi zgolj kot dekorativno prizorišče za zgodbe, polne intrig, nasilja in seksa (Tudorji, Borgijci), predstavljene kot zgodovinske (anti)romance, ki pa se osredotočajo zgolj na elito. Zgodovinski roman druge vrste pa so ustvarile nekatere nadaljevanke, ki (navidez s povsem drugega konca) celo iz ozadja izključijo vsa zgodovinska dejstva in predstavijo vsakdanjost navadnih ljudi v njeni (kvazi)historični drugosti. V nadaljevankah kot Mad Men in The Knick denimo ni omenjen noben političnozgodovinski dogodek, prav tako se v ozadju ne pojavi nobena zgodovinska osebnost, vendar pa te uspešno predstavljajo drugost preteklosti z gledišča javnega diskurza o vprašanjih rase, spola in celo morale, fenomenov, 
ki jih je mogoče videti kot razvoj nove vrste historičnega romana, spodbujene $s$ historiografskimi ideali dvajsetega stoletja.

1.01 Izvirni znanstveni članek / Original scientific article

UDK 316.77:621.397.13

075.2:82.0-311.6

D0I: https://doi.org/10.3986/pkn.v43.i1.05 